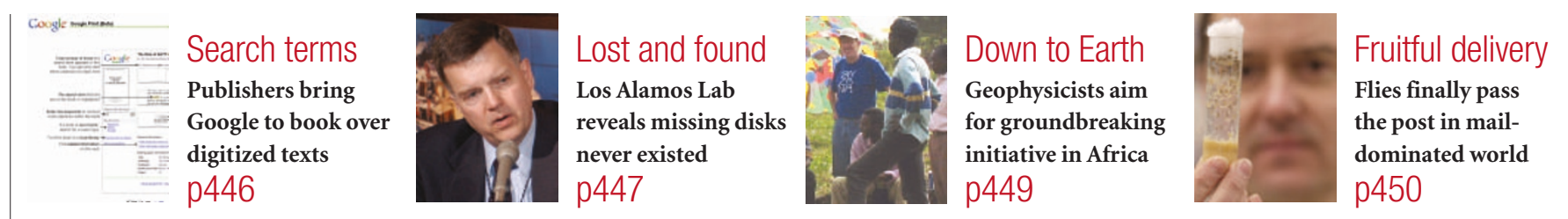

\title{
DNA is burning issue as Japan and Korea clash over kidnaps
}

David Cyranoski, Tokyo

A bitter dispute has erupted between Japan and North Korea over DNA tests used to establish whether cremated remains belong to a Japanese citizen abducted in 1977.

The argument is the latest twist in an episode that has soured relations between the two countries for years. During the 1970s and 1980s, North Korea was believed to have abducted at least 13, and perhaps as many as 100, Japanese citizens to work in its espionage programme. Now the two nations are falling out over the feasibility of correctly identifying DNA from the ashes of one of those abducted.

In the autumn of 2002, North Korea ended years of denials and admitted that members of its armed forces abducted 13 Japanese citizens from Japan and Europe. The North Korean leader, Kim Jong-il, claimed that the abductions were carried out by the military without government permission. Japan says it has evidence of two more abductees, and believes that there were in fact many more.

Pressure on North Korea to release survivors has since seen five abductees return to Japan accompanied by their families. Information on eight others, which North Korea says are dead, has been slow to arrive, leading to speculation that some of them are still alive.

On 15 November last year, Japanese officials returned from talks in Pyongyang carrying what North Korea claimed to be the cremated remains of Megumi Yokota, who was abducted in 1977 at the age of 13 . According to North Korean reports, Yokota married a North Korean, but later killed herself after entering a mental hospital.

At Teikyo University in Tokyo, tests on five samples of the ashes found DNA from two sources - but neither of them matched DNA from Yokota's umbilical cord, which had been kept by her parents, as is common in Japan. In December, these results were passed to North Korea, but on 26 January the Korean government issued a statement that branded them a "fabrication".

According to Hatsuhisa Takashima, a spokesman for Japan's foreign ministry, North Korea called into question the methods used in the tests and claimed that the remains,

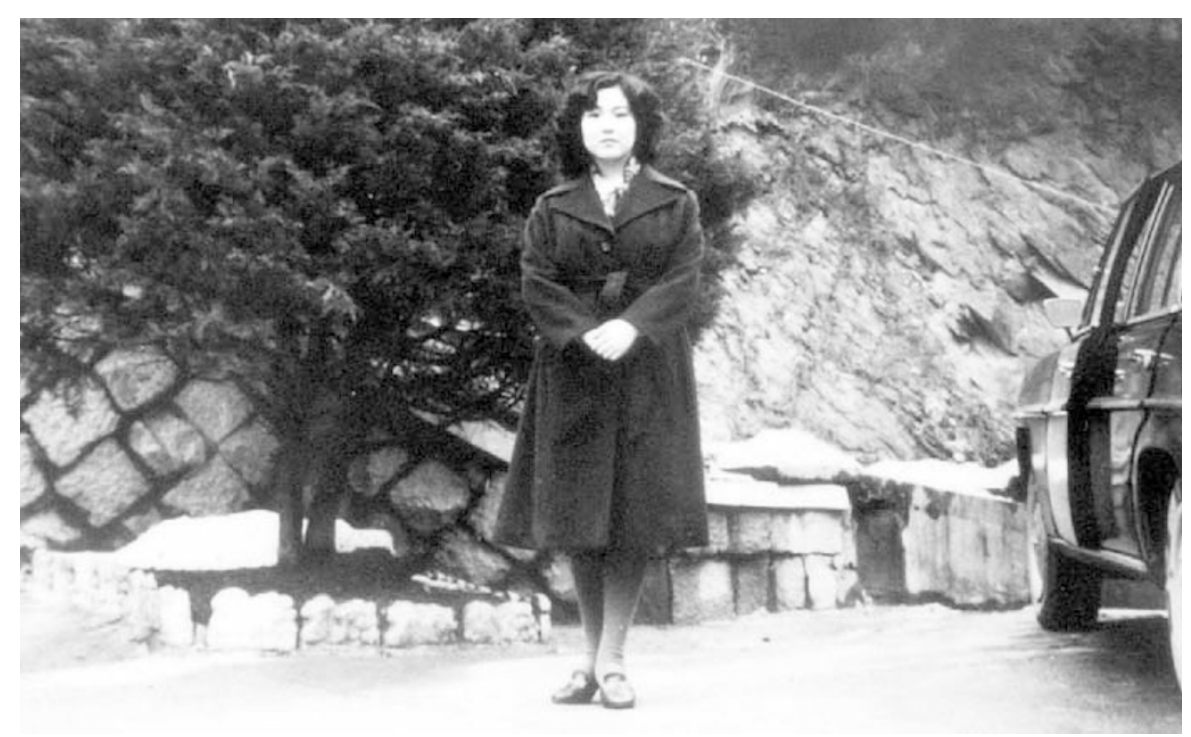

Missing: Megumi Yokota some years after her abduction, in a photo recently released by North Korea.

which had been heated to $1,200^{\circ} \mathrm{C}$, could not contain any surviving DNA. The North Korean statement also asked why researchers at Teikyo University were able to extract DNA when the National Research Institute of Police Science in Tokyo, which also had five samples to work with, had been unable to do so.

\section{Sample survival}

Teikyo University's Tomio Yoshii, one of Japan's leading forensics experts, says there are several reasons why he managed to extract DNA from all five of his samples. These include the fact that he used a highly sensitive process called the nested polymerase chain reaction (PCR), which amplifies DNA twice instead of once as in conventional PCR, and the possibility that his original samples were of better quality than those at the other lab. "Everyone has their own method" of handling DNA samples, he notes. "There is no standardization."

Little forensic work has been done on cremated specimens in Japan, and most experts, including Yoshii, thought it unlikely that DNA would have survived cremation at $1,200^{\circ} \mathrm{C}$. "I was totally surprised," says Yoshii. But DNA could survive if exposed to such heat for only a short time. "You can't tell anything from temperature alone," says Hirofumi Fukushima, a forensics expert at Shinshu University.

Nonetheless Yoshii, who has no previous experience with cremated specimens, admits his tests are not conclusive and that it is possible the samples were contaminated. "The bones are like stiff sponges that can absorb anything. If sweat or oils of someone that was handling them soaked in, it would be impossible to get them out no matter how well they were prepared," he says.

Takashima says that North Korea has sent remains that it said belonged to an abductee in the past, only to admit later that they were from another source.

The Japanese government responded to the current incident on 26 January by calling North Korea's handling of the situation "deplorable". It threatened "stringent actions" that, according to Takashima, may include the cancellation of 125,000 tonnes of food aid and other trade sanctions.

Japanese officials also say that they want to retest the DNA in question. But Yoshii says his five samples - the largest of which weighed only 1.5 grams - were used up in his tests. And that, observers say, leaves little prospect of the disagreement being resolved. 